\title{
Exploiting high frequency monitoring and satellite imagery for assessing chlorophyll-a dynamics in a shallow eutrophic lake
}

\author{
Monica Pinardi, ${ }^{1}$ Gary Free, ${ }^{1}$ Beatrice Lotto, ${ }^{2}$ Nicola Ghirardi, ${ }^{1,2}$ Marco Bartoli, ${ }^{2,3}$ Mariano Bresciani ${ }^{1 *}$ \\ ${ }^{1}$ National Research Council, Institute for Electromagnetic Sensing of the Environment, via Bassini 15, 20133 Milan, Italy; ${ }^{2}$ Department \\ of Chemistry, Life Sciences and Environmental Sustainability, University of Parma, Parco Area delle Scienze 33/A, 43124 Parma, Italy; \\ ${ }^{3}$ Marine Science and Technology Center of Klaipeda University, LT-92294 Klaipeda, Lithuania
}

\begin{abstract}
Freshwater ecosystems are challenged by cultural eutrophication across the globe, and it is a priority for water managers to implement water quality monitoring at different spatio-temporal scales to control and mitigate the eutrophication process. Phytoplankton abundance is a key indicator of the trophic and water quality status of lakes. Phytoplankton dynamics are characterized by high spatio-temporal variation, driven by physical, chemical and biological factors, that challenge the capacity of routine monitoring with conventional sampling techniques (i.e., boat-based sampling) to characterise these complex relationships. In this study, high frequency in situ measurements and multispectral satellite data were used in a synergistic way to explore temporal (diurnal and seasonal) dynamics and spatial distribution of Chlorophyll-a (Chl-a) concentration, a proxy of phytoplankton abundance, together with physico-chemical water parameters in a shallow fluvial-lake system (Mantua Lakes). A good agreement was found between Chl-a retrieved by remote sensing data and Chl-a fluorescence data recorded by multi-parameters probes $\left(\mathrm{R}^{2}=0.94\right)$. The $\mathrm{Chl}-\mathrm{a}$ maps allowed a seasonal classification of the Mantua lakes system as eutrophic or hypertrophic. Along the Mantua lakes system an increasing gradient in Chl-a concentration was recorded following the transition from a fluvial to lacustrine system. There was significant seasonal heterogeneity among the subbasins, probably due to different hydrodynamics, influenced also by macrophyte stands. High-frequency data revealed the importance of rainfall events in the timing and growth dynamics of phytoplankton, particularly for spring and late summer blooms. Combining temporal and spatial data at high resolution improves the understanding of complex fluvial-lake systems. This technique can allow managers to target blooms in near-real time as they move through a system and guide them to localized hot spots enabling timely management action in ecosystems of high conservation and recreational value.
\end{abstract}

\section{INTRODUCTION}

Freshwaters are an essential resource for life at global level and perform important functions in the environment (Boggero et al., 2014), provide habitat for numerous species, form essential components in hydrological and

Corresponding author: bresciani.m@irea.cnr.it

Contributions: All the authors made a substantive intellectual contribution. All the authors have read and approved the final version of the manuscript and agreed to be accountable for all aspects of the work.

Conflict of interest: The authors declare that they have no competing interests, and all authors confirm accuracy.

Key words: Remote sensing; trophic state; monitoring; lakes; Chla fluorescence; Sentinel-2.

Received: 8 May 2021.

Accepted: 15 June 2021.

This work is licensed under a Creative Commons Attribution NonCommercial 4.0 License (CC BY-NC 4.0).

${ }^{\circ}$ Copyright: the Author(s), 2021

Licensee PAGEPress, Italy

J. Limnol., 2021; 80(3):2033

DOI: 10.4081/jlimnol.2021.2033 nutrient cycles (Moss, 2012), and their services support food, water and energy security (Hanjra and Qureshi, 2010; Carpenter et al., 2011, Stendera et al., 2012; Carvalho et al., 2013). Nevertheless, eutrophication of freshwater ecosystems resulting from nitrogen $(\mathrm{N})$ and phosphorous $(\mathrm{P})$ pollution is a major stressor worldwide (Bennet et al., 2017). In fact, nutrient enrichment triggers a progression of eutrophic responses in aquatic ecosystems (Smith, 2003; Conley et al., 2009). The most evident is the significant increase of primary producers' abundance that are directly correlated and rapidly responds (i.e., hourly/daily) to high $\mathrm{N}$ and $\mathrm{P}$ loads into inland and coastal waters (Carpenter, 2008). Understanding the relationship between eutrophication processes and inland waters functional aspects has been a priority for water managers to mitigate and control eutrophication at different spatio-temporal scales (Vargas-Lopez et al., 2021).

Phytoplankton is characterized by circadian variability, as well as by diurnal rhythms and seasonal variability, driven by physical and biological factors such as light intensity, water temperature, wind, water level, nutrients, species, and size (Carstensen et al., 2007; Moore et al., 2008; Leal et al., 2009; Zhang et al., 2012; Jindal and Thakur, 2013; de Tezanos Pinto and O' Farrel, 2014; Bowes et al., 2016). For this reason, lake routine monitoring and water quality assessment with conventional sampling techniques, such as boat based sampling with filtration of water samples followed by laboratory analysis 
(e.g., solvent extraction of chlorophyll-a and spectrophotometric determination), are challenged to provide insights into the complex relationship between biological, chemical and physical processes (Kaplan et al., 2003; Polat et al., 2005; Bresciani et al., 2013, Klemas et al., 2013; Kiefer et al., 2015; Huang et al., 2015). An appropriate spatial and temporal characterization of phytoplankton blooms together with information on rapidly changing temperature, light, water discharge, precipitation, and nutrients are still a challenge in aquatic ecosystems (Bowes et al., 2016; Brentrup et al., 2016; Vargas-Lopez et al., 2021).

Chlorophyll-a (Chl-a) is a photosynthetic pigment used to indicate phytoplankton biomass and is considered a proxy to determine the trophic state and water quality status in lakes (Falkowski and Kiefer, 1985; Steinman et al., 2006; Matthews, 2017). The measurement of the diurnal variation of Chl-a concentration is a fundamental factor to investigate short-term dynamics, because the phytoplankton blooms can grow and dissipate within a few days (growth rate of $0.1-0.86 \mathrm{~d}^{-1}$ as reported by Reynolds, 2006). This short-term variability can influence the seasonal structure and phenology of phytoplankton distribution (Woods et al., 2021), and therefore the monitoring needs also to detect annual variations in bloom magnitude and timing over a medium-long term period (Bowes et al., 2016). One of the main approaches to determine Chl-a concentration is based on the Chl-a fluorescence used in both in situ continuous fluorimetry measurements (Laney, 2010; Pan and Qiu, 2019), and in optical sensors that indirectly estimate in situ fluorescence and, in addition, allow the assessment of phytoplankton abundance at large spatial scale (Huot and Babin, 2010; Ha et al., 2017). Recent advances in developing sensors and observation platforms, and in particular of accurate chlorophyll fluorescence probes offers an opportunity to produce the high-frequency, long-term Chl-a concentration data useful to investigate understudied subsurface features (Catherine et al., 2012; Bowes et al., 2016). In addition, Chl-a fluorescence sensors mounted on a buoy have the advantage of remotely measuring nightly, assuring more stable and accurate Chl-a values than with manual daytime sampling (Brentrup et al., 2016). A potential limit of using in vivo fluorescence as a proxy of phytoplankton biomass occur when there is nonphotochemical solar quenching due to phytoplankton exposure to excess light energy, producing a reduction in fluorescence quantum yield (Morrison et al., 2003; Hamilton et al., 2010). Another possible limit of these instruments in turbid and eutrophic waters can be the accumulation of organic and inorganic material, that require moderate-high frequency management operations to clean the probes to avoid a significant loss of accuracy (Bresciani et al., 2013). Even if, $\mathrm{Chl}-\mathrm{a}$ is well correlated to in vivo fluorescence, there are interfering compounds that can affect this relationship, and therefore separating the contribution of the water column and that of the phytoplankton cells in optical signals is still a major issue (Bergamino et al., 2010; VargasLopez et al., 2021). For this reason, observations gathered from in situ continuous fluorimetry sensors are a useful tool to integrate and validate with measurements of Chla concentration both via spectrophotometry and with satellite Chl-a concentration products.

Satellite imagery provides synoptic, fast and repeated information on aquatic environments identifying lake areas with different characteristics and seasonal variation improving strategies for water management (Duan et al., 2009; Liu et al., 2009; Odermatt et al., 2012; Huovinen et al., 2019). Earth Observation (EO) data can complement in situ sampling of inland waters given its multi temporal and spatial distribution capabilities, while boat-based sampling can measure responses at a finer scale and detail compared to remote sensing products (Bukata et al., 2005; Schaeffer et al., 2013, Hestir et al., 2015; Palmer et al., 2015; Tyler et al., 2016). Lake monitoring methodologies strengths and weaknesses can be maximized and minimized in a complementary way using remote sensing products and in situ measurements. In addition, current and upcoming sensors, open access and free data policies (Oppelt et al., 2015) and open source tools will further develop the use of EO data in lake research and monitoring (Dörnhöfer and Oppelt, 2016; Topp et al., 2020). For example, the recently Sentinel-2, with a twin configuration (A and B), a spatial resolution up to $10 \mathrm{~m}$ and a revisiting time of 5 days, of the $\mathrm{EU}$ Copernicus Programme, offer a great opportunity to monitor water quality parameters with medium-high frequency and fine spatial scale (e.g., Toming et al., 2016; Ansper and Alikas, 2019; Bresciani et al., 2020).

In fact, satellite remote sensing data have been used to retrieve Chl-a maps for water quality monitoring (Lindell et al., 1999; Gilerson et al., 2010; Bresciani et al., 2017; Pinardi et al., 2018) going beyond the limited temporal frequency and spatial coverage of in situ sampling (Tyler et al., 2016, Kiefer et al., 2015; Dörnhöfer et al., 2018). Temporal variations involve diurnal and seasonal dynamics and multi-annual cycles, and spatial variations include changes within and between aquatic ecosystems at catchment scale (Duan et al., 2009; Wang et al., 2011; Nõges et al., 2012).

In European countries the Water Framework Directive (WFD) (2000/60/EC) is legislation that aims to protect and enhance aquatic ecosystems and promote sustainable water use across Europe (European Commission, 2000). Recently, Carvalho et al. (2019) reported that there is growing concern that the objective of good status in all European waters by 2027 is a long way from being achieved in many countries, and they evaluated the strengths and weaknesses of the current WFD implemen- 
tation in order to identify where innovation offers new opportunities for monitoring and management. The current study aims to provide an example of a practical implementation of improvements, aiming to achieve the classification of water quality status with satellite images and Chl-a maps representative of the whole water body capitalizing on the availability of data with a weekly-monthly frequency. This improved spatio-temporal scale provides a more robust and realistic dataset of Chl-a concentration distribution and dynamics. Moreover, the sub-annual analysis of Chl-a values is of great importance to better define and interpret the phytoplankton biomass phenology and distribution with the aim of supporting local water management plans identifying the best spatio-temporal scale for control and restoration actions. In this context, the present study uses in a synergistic way high frequency in situ measurements with satellite remote sensing data for assessing temporal dynamics and spatial heterogeneity of phytoplankton abundance, trophic-state and physicochemical parameters in Mantua Lakes, a shallow eutrophic fluvial-lake system located in Northern Italy. The main aims were to: i) compare the Chl-a satellite derived data against continuous in situ fluorimeters data; ii) use remote sensing data to evaluate seasonal phytoplankton abundance dynamics and intra-lake spatial variation; iii) analyse daily evolution of bio-physico-chemical water parameters from the in situ continuous measurements (Chla, water temperature, and conductivity); iv) analyse the relationship between the bio-physical-chemical variables and meteo-climatic and hydrometric level data.

\section{METHODS}

\section{Study area}

The Mincio River watershed hosts the shallow fluviallake system composed by the Mantua Lakes (Superior, Middle and Inferior, surface area of $6.22 \mathrm{~km}^{2}$ ) and two protected wetlands (Valli del Mincio and Vallazza) located upstream and downstream of the lakes, respectively (Northern Italy; $45^{\circ} 10^{\prime} \mathrm{N}, 10^{\circ} 47^{\prime} \mathrm{E}$; mean depth $3.5 \mathrm{~m}$; Fig. 1). The main activities are agriculture and livestock farming (Pinardi et al., 2018). The origin of this system dates back to the XII century when the Vasarone dam was built along the river course between the Superior and Middle lakes. The water residence time is of the order of days, and the water flow is regulated by Vasarone (since 1190) and Vasarina (hydroelectric power plant built in 2015) dams with the aim of guarantee a stable maximum water level $(17.5 \mathrm{~m}$ on the Superior Lake, and $14.5 \mathrm{~m}$ on the Middle and Inferior lakes), and to avoid the flood risk for Mantua city (Pinardi et al., 2015). These shallow fluvial lakes and wetlands are a protected area characterized by eutrophic, turbid waters and are mainly colonized by the coexistence of different phytoplankton groups (e.g., diatoms, green algae, and cyanobacteria) and macrophyte

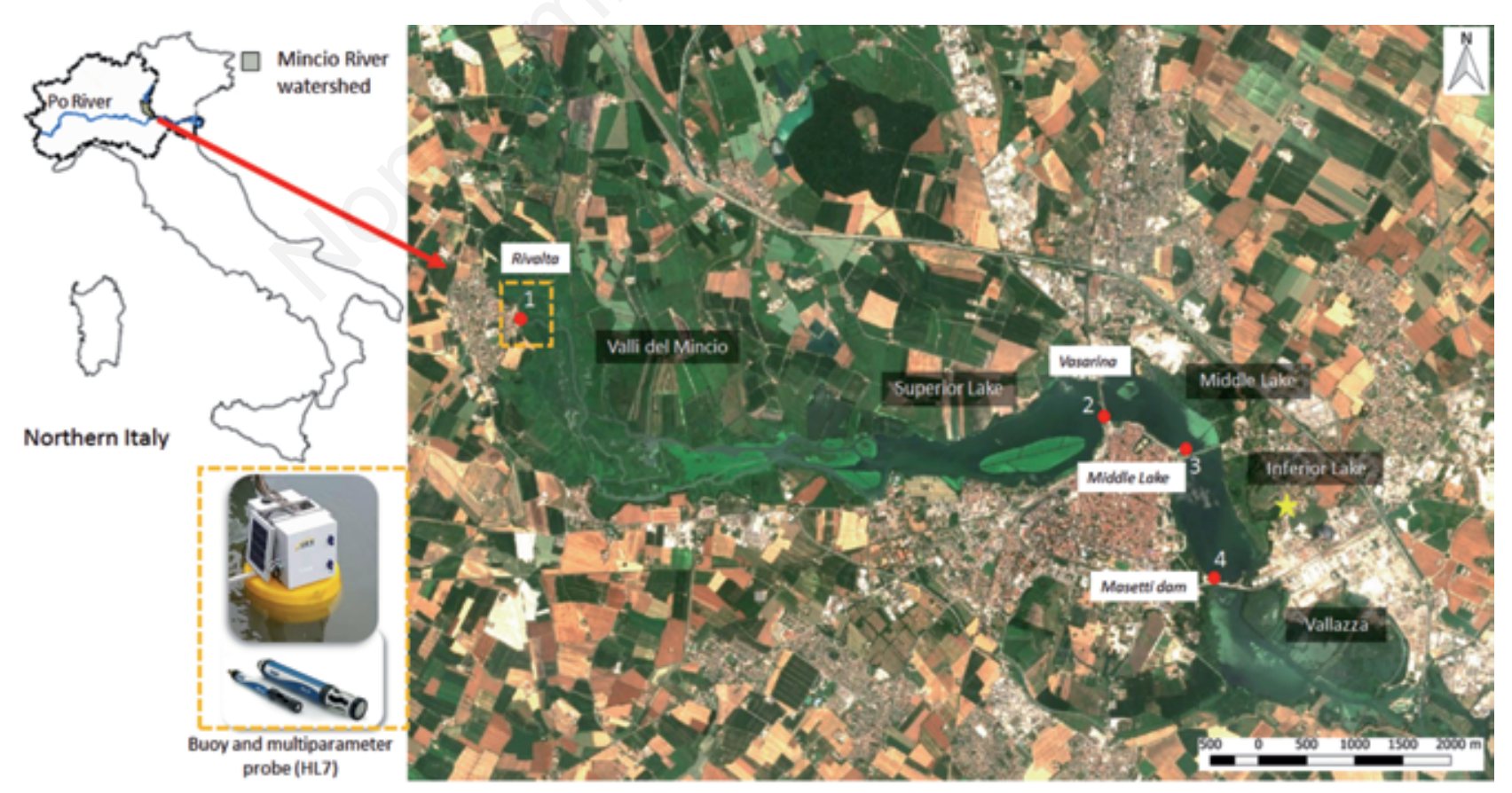

Fig. 1. Maps of the Mantua Lakes (Superior, Middle and Inferior) and Valli del Mincio and Vallazza wetlands. The buoy locations are reported with red dots: 1. Rivalta, 2. Vasarina, 3. Middle Lake, 4. Masetti Dam. The "Mantova (Lunetta)" weather station is reported (yellow star). Picture of the buoy and HL7 multiparameter probe is also reported (orange box). Sentinel-2 image of 26 June 2019. 
communities (submersed, floating, and emergent) (Pinardi et al., 2020, 2021; Villa et al., 2017). The fluvial-lake system is characterized by low water transparency (Secchi disk mean value between 0.8 and $1.3 \mathrm{~m}$; ARPA Lombardy dataset from 2009 to 2016), especially in summer due to high phytoplankton (up to $140 \mathrm{mg} \mathrm{m}^{-3}$; ARPA Lombardy dataset from 2009 to 2016) and suspended solids concentrations (up to $30 \mathrm{mg} \mathrm{L}^{-1}$; ARPA Lombardy dataset from 2015 to 2019). Due to high nutrient (nitrate $-\mathrm{NO}_{3}-\mathrm{N}$ up to $7 \mathrm{mg} \mathrm{L}^{-1}$ and total phosphorous in the range from 35 to $158 \mu \mathrm{g} \mathrm{L}^{-1}$; ARPA Lombardy dataset from 2009 to 2016) and organic matter loads from upstream, and insufficient water discharge the Mantua lakes system is subject to a rapid infilling, which result in a net accumulation of organic carbon within the system with a high risk of hypoxia and anoxia (Pinardi et al., 2011; Bolpagni et al., 2014).

\section{Ancillary data}

Meteorological data were obtained by ARPA Lombardy meteorological service. The sub-hourly or daily data of the following parameters were downloaded for the period from 01/01/2018 to 30/12/2020 for the "Mantova (Lunetta)" station (Fig. 1): air temperature, precipitation, humidity, global radiation, and wind speed and direction. Cloud cover was obtained from the online database ERA5 available from the Climate Data Store of Copernicus, covering the years investigated.

Hourly and daily hydrometric level data were downloaded from the automated stations Vasarone both for the Superior and Middle lakes from the Interregional Agency for the Po River (AIPO, Mantua branch). The former data were coupled with Rivalta and Vasarina multi-parameters probes and the latter with the Middle Lake and Masetti dam probes.

Water quality parameters from samples taken at the center of Superior, Middle and Inferior lakes measured bimonthly (6 data per lake per year) by ARPA Lombardy were available on line and downloaded for the years 2018 and 2019). This in situ dataset was used to classify seasonally and annually the trophic-state of the three lakes of Mantua according to OECD (1982).

\section{Satellite images and Chl-a concentration maps}

Chlorophyll-a concentrations were retrieved from Sentinel-2 images. The Sentinel-2 satellite is equipped with the Multi-Spectral Instrument (MSI), a passive optical sensor with 13 spectral bands covering the electromagnetic spectrum in the wavelengths of visible infrared shortwave (440-2200 nm), with an orbital swath of about $290 \mathrm{~km}$ on the ground, a revisit time of 5-10 days and a spatial resolution of 10,20 or $60 \mathrm{~m}$ (depending on the band). In the period between April 2018 and June 2020, a total of 27 images were downloaded for the following pro- cessing. The dates were chosen synchronous of proximal (up to 1 month; Fig. 1 and Tab. 1 in Supplementary Material 1) to the installation or maintenance of the multiparameter probes to validate the two datasets, as after this operation the in situ measurements are probably more reliable (e.g., absence of biofilm on the sensors). The images were downloaded at Level 2A from the Open Access Hub of Copernicus. The Level-2A product provides Bottom Of Atmosphere (BOA) reflectance images derived from the associated Level-1C products atmospherically corrected using Sen2Cor processor. Each Level-2A product is composed of $100 \times 100 \mathrm{~km}^{2}$ tiles in cartographic geometry (UTM/WGS84 projection).

The bands of the Level-2A images were resampled at $10 \mathrm{~m}$ and a spatial subset of the tile on the study area was performed using the SNAP (Sentinel Application Platform) software (ver. 8). Then the BOA reflectance was corrected for specular effect and converted in Rrs according to Mobley (1999). Then the image was masked to remove all pixels not classified as water. Finally, the validated algorithm $\left(\mathrm{R}^{2}=0.93\right.$; MAE (mean absolute error) $=4.64 \mathrm{mg} \mathrm{m}^{-3}$; rRMSE (relative root-mean-square error $=20.18 \%$; Pinardi et al., 2018) to retrieve Chl-a concentration for the Mantua lakes system parametrized with numerous in situ measurements acquired in Mantua Lakes (Bresciani et al., 2013; Bresciani et al., 2017) was applied to all water pixels of the 27 images, as follow:

$$
\text { Chl- } a\left(\mathrm{mg} \mathrm{m}^{-3}\right)=76.36( \pm 2.29) \frac{\operatorname{Ref}_{(705)}}{\operatorname{Ref}_{(65)}}-51.57( \pm 0.26)
$$

where $\operatorname{Ref}(665 \mathrm{~nm})$ and $\operatorname{Ref}(705 \mathrm{~nm})$ are the atmospherically corrected reflectance in bands 4 and 5 , respectively.

The images of 03/07/2019 and 06/07/2019 had some errors in reflectance values (negative values in the blue regions and anomaly higher values in the NIR region), so they were downloaded at Level $1 \mathrm{C}$ and atmospherically corrected using the 6SV code (Second Simulation of Satellite Signal in the Solar Spectrum) which is a Radiative Transfer Model (Vermote et al., 2006). The code was parametrized with Aerosol Optical Thickness (AOT) and aerosol microphysical properties information at the time of imagery acquisition, collected from AERONET stations near the study area (Sirmione_Museo_GC) and with a standard percentage of aerosol composition for North Italian Po Valley (Bresciani et al., 2018). The 6SV products obtained were corrected for specular effect and converted in Rrs according to Mobley (1999). The maps produced were grouped by season: 8 for spring, 12 for summer, 3 for autumn, and 4 for winter (Tab. 1 in Supplementary Material 1). The trophic status of the Mantua Lakes system was estimated seasonally and annually using the mean Chl-a concentration in accordance with the OECD classification (OECD, 1982; Chl-a mean (or maximum) value, in $\mathrm{mg} \mathrm{m}^{-3}$ units: $<1(<2.5)$ ultra-olig- 
otrophic, $<2.5(<8)$ oligotrophic, $2.5-8(8-25)$ mesotrophic, $8-25(25-75)$ eutrophic, $>25(>75)$ hypereutrophic $)$.

\section{In situ water bio-physico-chemical parameters}

Hydrolab HL 7 multi-parameter probes equipped with different sensors were used to measure with high-frequency the following parameters: fluorimetric chlorophyll-a, water temperature, and conductivity (Tab. 2, Supplementary material 1). Each multi-parameter probe is fixed on a circular buoy equipped with a GPS device and two solar panel for energy power. The station manager is the datalogger OTT net DL 500 with a modem GSM/GPRS for the remote transmission of the data. The buoys were located in four sites, from upstream to downstream the study area: Rivalta, Vasarina, Middle Lake and Masetti dam (Fig. 1). Data were collected from 16 April 2018 to 30 June 2020. Data measurements were every 10 min until 26 November 2018 and then every 15 minutes. The optimal timing for ordinary maintenance of the sensors is 30-60 days. The dates of the multi-parameter probes maintenance at Mantua Lakes are reported in Fig. 1 and Tab. 3 in Supplementary material 1. This optimal maintenance time schedule was not respected during winter months and during the lockdown period due to COVID-19 pandemic (Tab. 3 in Supplementary material 1). On three occasions (18/07/2018; 16/05/2019; $22 / 01 / 2020$ ), water samples were collected, filtered (with $\mathrm{GF} / \mathrm{F}$ glass fiber filters) and analysed by the Laboratory of Aquatic Ecology of the University of Parma to determine Chl-a concentration (via acetone $90 \%$ extraction and spectrophometric detection according to APHA, AWWA, WPCF, 1981) synchronous to the calibration of the fluorimetric sensors.

\section{Statistical analysis}

\section{Comparison of Chl-a data}

To test the reliability of the integration of the different datasets of Chl-a (in situ fluorimetric and spectrophotometric, and satellite data) a comparison between continuous fluorimetric data recorded in situ and remote sensing data from Sentinel-2 were performed together with the comparison between in situ fluorimetric data and spectrophotometric data. Satellite derived data have been previously compared and validated with spectrophotometric readings obtained in field campaigns at Mantua Lakes as reported in Pinardi et al. (2018).

Three regions of interest (ROIs) were created on all the 27 Chl-a maps of the Mantua Lakes to extract concentration values to be used for the comparison with in situ fluorimetric data (time of EO acquisition \pm 1 hour) (Fig. 1 in Supplementary Material 1). Each ROIs of 9 pixels (3x3) were selected including the buoys station of the Mantua Lakes (Vasarina, Middle Lake and Diga Masetti sites). The Rivalta's buoy is located in the Mincio River and the width of the riverbed is too narrow for the $10 \mathrm{~m}$ pixel size of Sentinel-2.

The comparison between continuous Chl-a data recorded in situ and Chl-a measured in lab was done for the three dates of field sampling in the four sites where the buoys are located (Fig. 1 in Supplementary Material 1). MAE (Mean absolute error) and RMSE (Root-meansquare error) were used as a measure of the error for the comparison between the observed data.

\section{Spatial analysis}

The temporal analysis of 24 images (March-September) was done in a GIS environment (QGIS 3.16 software), using the same reference system (WGS84) and cartographic projection (UTM Zone $32 \mathrm{~N}$ ). The period of analysis was from March to September when the algal bloom events are periodic and can influence the water quality status of this shallow turbid system. The GRASS function (r.series) was used to obtain maximum, mean and standard deviation, and raster calculator tool was used to calculate the coefficient of variation $(\mathrm{CV}=$ standard deviation/mean) of the temporal series for each pixel of Mantua Lakes.

\section{High frequency data analysis}

The analysis was based on the year 2019 as this represented a complete dataset from January to December for three multiprobes (Rivalta, Middle Lake, Masetti dam) whereas the Vasarina multiprobe was subject to vandalism and was nonfunctional for a large part of 2019 (see Table 3 in Supplementary material 1). Before analysis of the high frequency data recorded by the multiprobes, outliers were removed using a Hampel filter outlier detection, based on the absolute deviation from the median (Pearson et al., 2016), using the package "pracma" in R (R Core Team 2017). To exclude Chl-a fluorescence values associated with non-photochemical quenching (NPQ), only nighttime (from 00:00 to 04:00 am) data were used for all analyses. NPQ often occurs at higher irradiance, so shallow and turbid surface waters are more prone to this phenomenon (Brentrup et al., 2016).

Nonparametric Multiplicative Regression (NPMR) (McCune, 2006) was used to estimate the response of daily Chl-a to the climate and environmental parameters: day of year (DOY), lake level, lake surface water temperature, wind vectors, cloud cover, conductivity, radiation, daily rain total and the sum of the antecedent rain for seven days. As night-time Chl-a was used, the values were matched with the environmental values of the preceding day. The response of Chl-a was estimated using a local mean multiplicative smoothing function with Gaussian weighting. NPMR models were produced by adding pre- 
dictors stepwise with fit expressed as a cross-validated $\mathrm{R}^{2}$ $\left(x R^{2}\right)$ which can be interpreted in a similar way as a measure of fit as a traditional $\mathrm{R}^{2}$. The sensitivity, a measure of influence of each parameter included in the NPMR model, was estimated by altering the range of predictors by \pm 0.05 (i.e., 5\%) with resulting deviations scaled as a proportion of the observed range of the response variable. Sensitivity can be used to evaluate the relative importance of variables included in models because NPMR models differ from linear regression and have no fixed coefficients or slopes.

\section{RESULTS}

\section{Ancillary data}

Meteorological and water physico-chemical data measured by ARPA Lombardy are reported in Supplementary material 2 (Tab. 1, Fig. 1). The annual precipitation was similar in 2018 and 2020 (670 and $700 \mathrm{~mm}$, respectively), but higher in 2019 (964 mm). The maximum mean hourly value of solar radiance was comparable in the three years analysed (977, 1040 and $991 \mathrm{~W} \mathrm{~m}^{-2}$, respectively). Air temperature ranged between $-2.4^{\circ}$ and $31.7^{\circ} \mathrm{C}$, and mean wind velocity was $1.8 \pm 0.8 \mathrm{~m} \mathrm{~s}^{-1}$ in the period from 2018 to 2020.

In the period 2018-2019, surficial water of the Mantua Lakes had a water temperature in the range $4-30^{\circ} \mathrm{C}$, a transparency from 0.6 to $1.7 \mathrm{~m}$, a median conductivity of $390-400 \mu \mathrm{S} \mathrm{cm}^{-1}$ with a peak value (up to $613 \mu \mathrm{S} \mathrm{cm}^{-1}$ in the Middle Lake) at the end of November 2019, and a dissolved oxygen saturation of $129 \pm 86 \%$. The total suspended solids displayed increasing concentrations moving from the Superior to the Inferior lake (median 5.5, 10.9, 13.8 $\mathrm{mg} \mathrm{L}^{-1}$ ). Also, Chl-a concentrations varied considerably (from 2.3 to $45.7 \mathrm{mg} \mathrm{m}^{-3}$ for the period 2018-2019) due to seasonal (spring and summer or late summer blooms) and spatial variations in the phytoplankton blooms. All nutrients had high variability, as follows: i) ammonium nitrogen varied between 0.01 to $0.15 \mathrm{mg} \mathrm{L}^{-1}$; ii) median nitrate concentrations were $1.4,1.2$ and $0.8 \mathrm{mg} \mathrm{L}^{-1}$ from the Superior to the Inferior lake (with a peak at the end of November
2019 up to $8.5 \mathrm{mg} \mathrm{L}^{-1}$ ); the total nitrogen patterns were comparable to that of nitrate, with a median value around $2 \mathrm{mg} \mathrm{L}^{-1}$; iv) orthophosphates followed a decreasing gradient from upstream to downstream (median 26, 19 and 6 $\mu \mathrm{g} \mathrm{L}^{-1}$ for Superior, Middle and Inferior lakes, respectively); v) total phosphorous median values were $72 \mu \mathrm{g}$ $\mathrm{L}^{-1}$ in the Superior Lake and $82 \mu \mathrm{g} \mathrm{L}^{-1}$ in the Middle and Inferior lakes; vi) a peak up to 110 and $140 \mu \mathrm{g} \mathrm{L}^{-1}$ were measured for orthophosphate and total phosphorous, again at the end of November 2019; vii) reactive silica concentration varied between 0.1 and $7.6 \mathrm{mg} \mathrm{L}^{-1}$ (this latter value refers to the end of November 2019) and showed a seasonal variation coupled to the spring diatom bloom (resulting in lower $\mathrm{SiO}_{2}$ concentrations).

\section{Chl-a concentrations and mapping}

The comparison between Chl-a concentration retrieved by satellite data and fluorimetric Chl-a measured in situ by the multiparameter probes shown a good agreement $\left(\mathrm{R}^{2}=0.94\right.$; $\mathrm{RMSE}=11.76 \%$; Fig. 2$)$.

The 27 maps of Chl-a concentration for the Mantua lakes system are reported in figure 1 in Supplementary material 3. A phytoplankton bloom was observed at the beginning of spring (in April 2018 and March 2019), and the highest Chl-a values were observed in mid July 2019 and in June 2020 (up to $130 \mathrm{mg} \mathrm{m}^{-3}$; Fig. 1 in Supplementary material 3). The seasonal and annual mean Chl-a concentration maps are reported in figure 3 . The maps show a high spatial heterogeneity in all seasons with a clear increasing gradient of Chl-a from upstream to downstream (Fig. 3).

The Mantua lakes system was always classified as hypereutrophic using the 27 images data for the investigated period 2018-2020, with the exception of the winter period when the whole lake system was classified as eutrophic (Tab. 1). Looking at a single sub-basin on a seasonal and annual basis, it is evident that there is a great variability of mean Chl-a concentration values, despite this, it does not result in assignment of a different or lower trophic state classification (Fig. 2 in Supplementary material 3). In addition, the trophic-status classification using the in situ ARPA dataset $(\mathrm{n}=36)$ showed an underestimation of

Tab. 1. Classification of the seasonal and annual trophic status of the Mantua Lakes based on the mean Chl-a concentration maps retrieved by Sentinel-2 data.

\begin{tabular}{lcccc} 
& Number of maps & Number of valid pixels & Chl-a mean $( \pm$ SD) & Classification \\
Spring & 8 & 335152 & $40( \pm 7)$ & Hypereutrophic \\
\hline Summer & 12 & $41( \pm 8)$ & Hypereutrophic \\
\hline Autumn & 4 & 494832 & $33( \pm 9)$ & Hypereutrophic \\
\hline Winter & 3 & 160100 & $21( \pm 8)$ & Eutrophic \\
\hline Annual & 27 & 125292 & $35( \pm 9)$ & Hypereutrophic
\end{tabular}




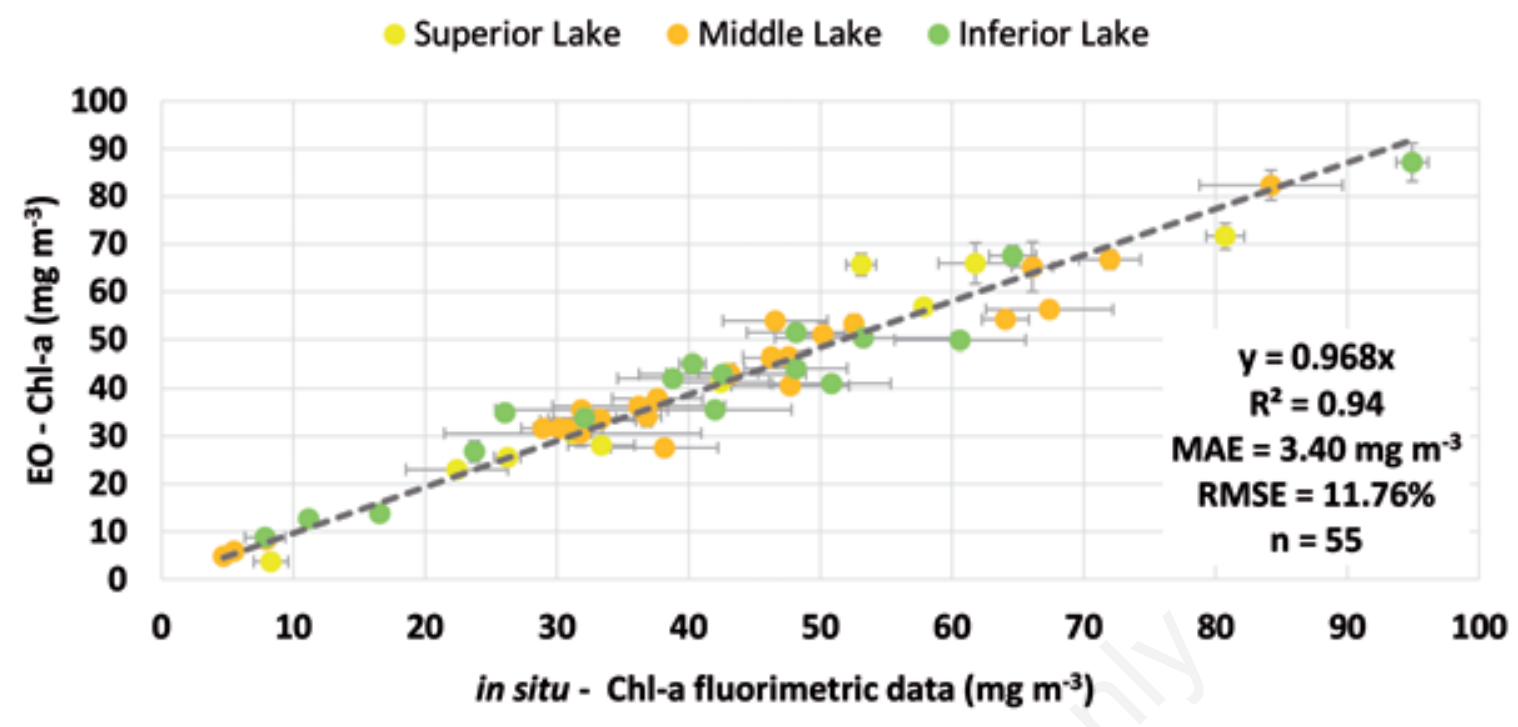

Fig. 2. Scatter plot of Chl-a concentration values measured by the fluorimeter of the multi-probes and retrieved by Earth Observation (EO) data. Standard deviation for EO data is the $3 \times 3$ pixels of the region of interest and for continuous data the value recorded \pm 1 hours from satellite acquisition.
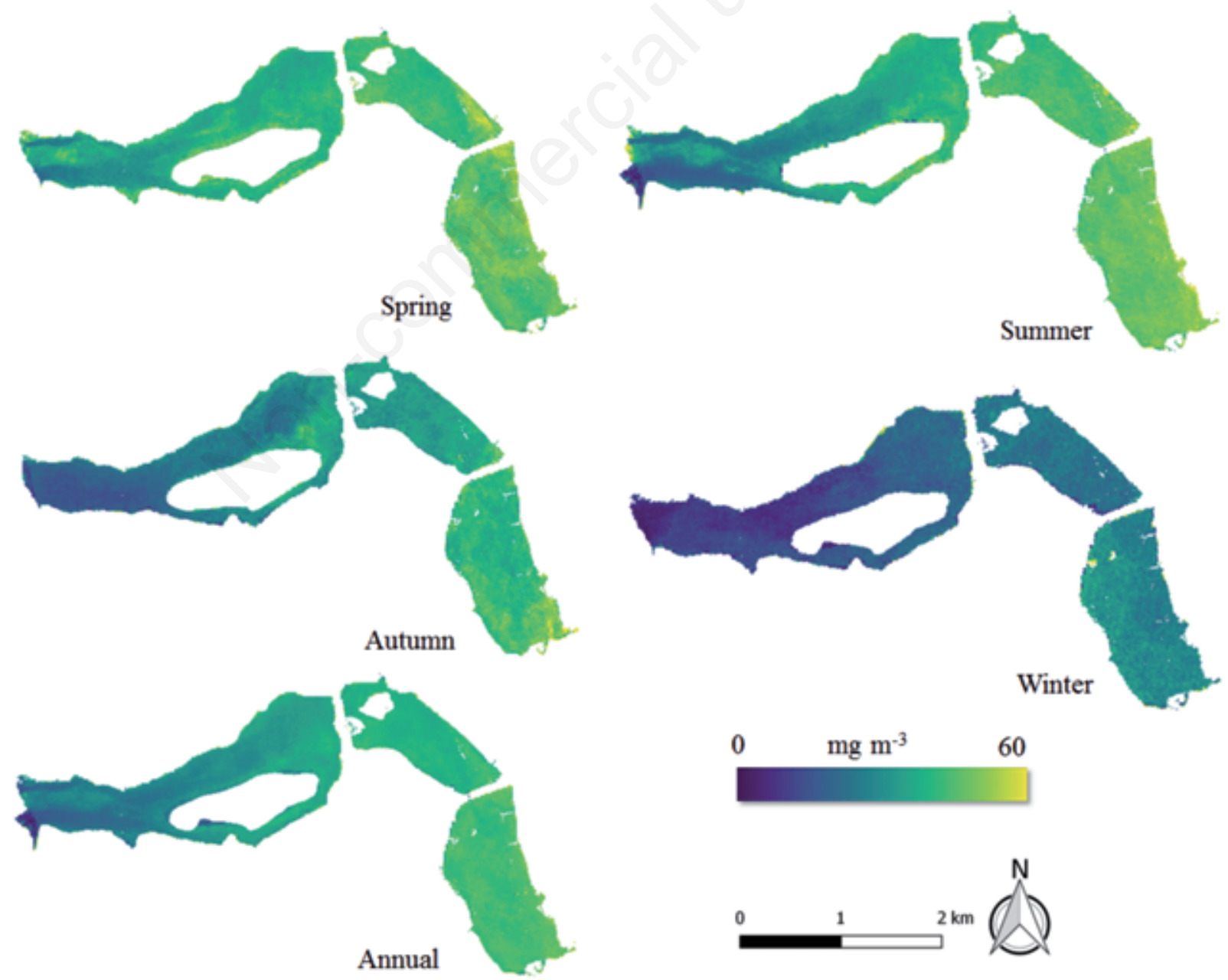

Fig. 3. Seasonal and annual mean Chl-a concentration maps for the period from 16 April 2018 to 30 June 2020 in Mantua Lakes. 
mean Chl-a concentration in autumn, and the winter value was influenced by the presence of an early algal bloom in the Inferior Lake both in 2018 and 2019 compared to the Sentinel-2 data-based classification (Fig. 2 in Supplementary material 3 ).

Focusing on the more productive period, between March and September, the mean Chl-a concentration of the Mantua lakes system shown higher values in the downstream portion of the Middle and in the Inferior lake (> $40 \mathrm{mg} \mathrm{m}^{-3}$ ) (Fig. 4). The minimum Chl-a concentrations also showed a gradient from upstream to downstream: minimum values were found in the fluvial portion of the Superior Lake with progressively higher values being found moving into the more lacustrine portion of the system (Middle and Inferior lakes; Fig. 4). The map of the maximum values is particularly interesting as it allows to immediately identify areas with the highest intensity of algal bloom (Fig. 4). In the Superior Lake the maximum values were detected in the portion of the lake where there is the transition between lotic and lentic waters and in the downstream portion of the lake (Fig. 4). In the Middle Lake in two areas close to the macrophyte stands the Chl-a concentration is higher compared to open water (Fig. 4). In the Inferior lake, which is characterized by sparse macrophyte plants, high Chl-a concentrations were retrieved in different portions of the system (Fig. 4).

The CV map of the Chl-a concentration for each pixel of the fluvial lake system shown a range between 0 and 0.7 for the period March-September (Fig. 4). The areas with the highest $\mathrm{CV}$ values were located in the upstream portion of the Superior Lake due to the highest standard deviation values of the pixels and a lower Chl-a concentration in the majority of the maps investigated.

\section{High frequency data analysis}

Comparing fluorimetric Chl-a data recorded in situ with that measured in the lab via spectrophotometry indicated a good relationship $\left(\mathrm{R}^{2}=0.91\right.$; RMSE $=33.5 \%$; Fig. 5).

Examining the seasonal variation in Chl-a for the three lakes it is apparent that the timing and growth dynamics of increases are influenced by rainfall events (Fig. 6). The influence of the first event centred on the $4^{\text {th }}$ of February 2019 can be seen to increase the conductivity successively downstream from Rivalta to Middle Lake to Masetti dam buoys. An almost immediate increase in Chl-a was ob- served in Rivalta while, after two weeks, higher concentrations were observed first in Masetti dam and then Middle Lake, despite Masetti dam being further downstream. Another bloom event was observed in Middle and Inferior lakes during September and October 2019, the onset of which appeared to coincide with high rainfall in the first week of September. No Chl-a increase was noted in Rivalta at this time and concentrations were low for much of the year after spring in this flow dominated site. The Chl-a pattern appeared more dynamic for Middle Lake with higher variation noted than for other sites. Temperature in Rivalta was higher in autumn-winter than the other sites but colder than the lake sites in spring and summer. Smaller scale variations in temperature, typically declines, coincided with rainfall events.

In order to further understand the factors influencing the dynamics of Chl-a in the Mantua lakes system we examined the high frequency data from the Rivalta, Middle Lake and Masetti dam sensors using Nonparametric Multiplicative Regression (NPMR) (Tab. 2). The models had an $\mathrm{xR}^{2}$ ranging from 0.75 to 0.85 and included DOY, antecedent rain for seven days or daily rain and the lake temperature. However, in the models for Rivalta and Middle Lake the antecedent rain was interchangeable with water temperature with no loss of performance $\left(\mathrm{xR}^{2}\right)$. The sensitivity value provides an indication of the importance of the variables in the models. The DOY had the highest sensitivity value (1.056 to 0.456 ) with the exception of the model for Masetti dam where lake temperature was higher $(0.579)$.

\section{DISCUSSION}

The integration of Sentinel-2 satellite data at mediumhigh spatial-temporal resolution with high-frequency continuous data allowed the assessment of the phytoplankton biomass at short (hourly/daily) and medium-term (seasonal/interannual) resolution. In addition, it also enabled assessment of the spatial heterogeneity together with the seasonal and annual variation of the trophic-state of the shallow fluvial-lake system affected by cultural eutrophication and anthropic impacts in the climate change scenario.

The first important result of this work is the good agreement between $\mathrm{Chl}$-a concentration retrieved by satellite and in situ fluorimetric data $\left(\mathrm{R}^{2}=0.94\right)$. Both datasets were also validated with Chl-a determined by spectropho-

Tab. 2. Results of NPMR (Nonparametric Multiplicative Regression) models for daily Chl-a for 2019.

\begin{tabular}{|c|c|c|c|c|c|c|c|c|c|c|c|c|}
\hline Lake & $\mathrm{xR}^{2}$ & Ave. size & Var.1 & Sen. & Tol. & Var.2 & Sen. & Tol. & Var.3 & Sen. & Tol. & p \\
\hline Rivalta & 0.84 & 20.2 & DOY & 0.528 & 18.2 & rain7day & 0.065 & 9.0 & & & & $\leq 0.05$ \\
\hline Middle Lake & 0.75 & 20.2 & DOY & 1.056 & 18.2 & rain7day & 0.119 & 9.0 & & & & $\leq 0.05$ \\
\hline Masetti dam & 0.85 & 19.0 & DOY & 0.456 & 18.2 & LSWT & 0.579 & 1.3 & rain & 0.007 & 15.7 & $\leq 0.05$ \\
\hline
\end{tabular}

$x R^{2}$, cross-validated $R^{2}$; Ave. size, average neighbourhood size; Tol., tolerance; Sen., sensitivity; LSWT, lake surface water temperature. 
metric measurements. This comparison is an essential step to allow the integration of these datasets in order to investigate phytoplankton dynamics at different spatial (from points to whole lake) and temporal (from sub-hourly to season) scales to expand our knowledge on complex shallow aquatic ecosystems (Huang et al., 2015).
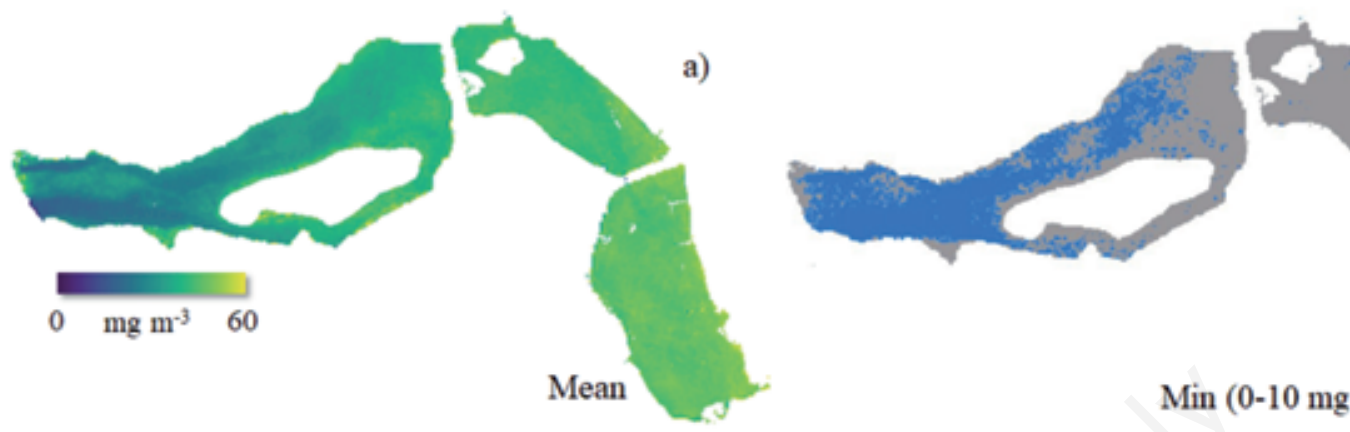

c)

$\operatorname{Min}\left(0-10 \mathrm{mg} \mathrm{m}^{-3}\right)$

b)
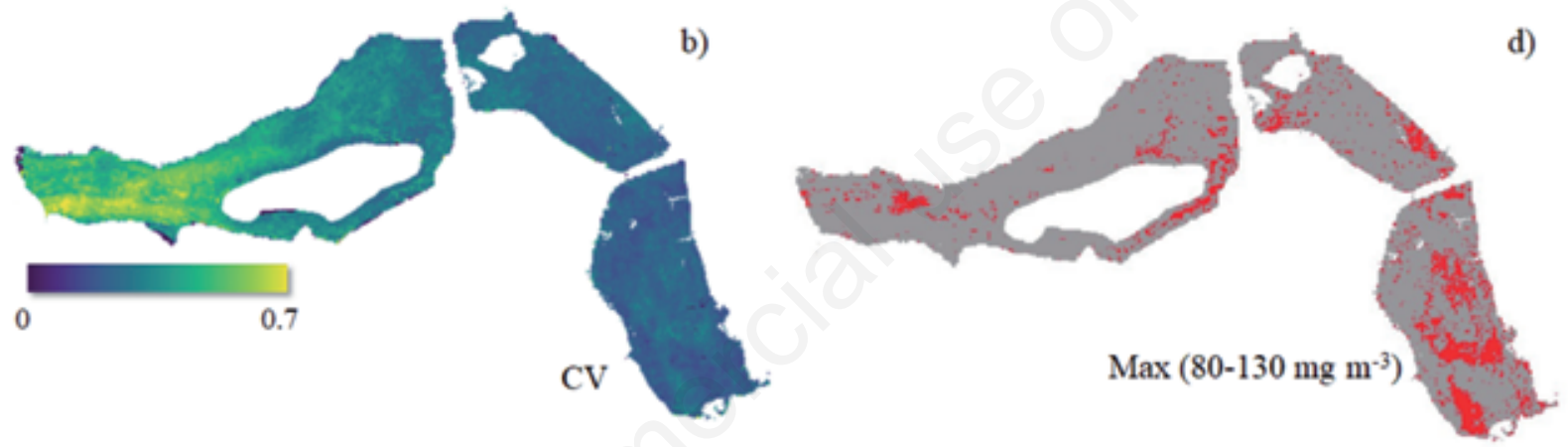

Fig. 4. Maps of Chl-a concentration mean (a), coefficient of variation (CV) (b), minimum (Min) (c), and maximum (Max) (d) of the 24 images acquired between March and September of the study period in Mantua Lakes.

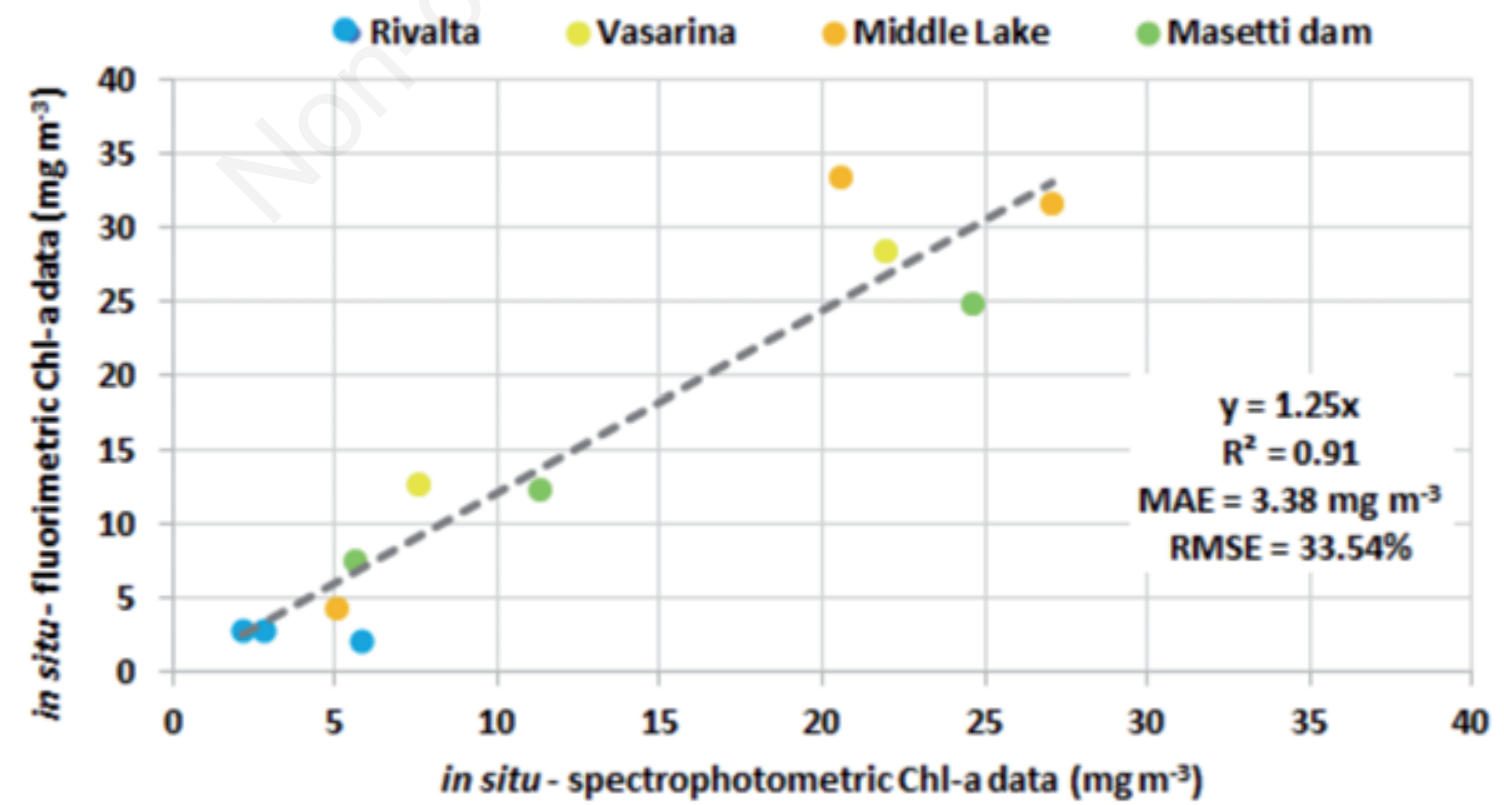

Fig. 5. Scatter plot of Chl-a concentration data measured by the fluorimeter of the multi-probes and in situ water samples analysed in laboratory via spectrophotometric technique. 
The conventional monitoring dataset of ARPA Lombardy showed that generally the Mantua Lakes are characterized by nutrient rich, turbid and highly productive waters with seasonal variation of ammonium, orthophosphate and reactive silica probably coupled with the phytoplankton phenology of different species. In accordance with this monitoring data, the results of the work confirm the persistence of the high trophic state (hypertrophic class) of this shallow fluvial-lake system on an annual basis and in all seasons, except in winter months (eutrophic class). These results are in agreement with the data reported in previous work on the same study area (Bolpagni et al., 2014; Pinardi et al., 2018). The spatial variation is important in this small shallow system, which is highly heterogeneous with an increase of Chl-a concentration moving from the more fluvial portion to the lentic downstream portion of the system. This river-to-lake gra- dient in Chl-a concentration differs, for example, from the findings of Gillett et al., (2015) in a small drowned-river mouth lake in the USA. They expected a phytoplankton spatial distribution reflecting the presence of three hydrologic zones, however no spatial patterns were evident in terms of phytoplankton biovolume and composition which can probably be explained by the small lake area and the horizontally well-mixed waters, due to low retention time (1-4 months) and water discharge. In Mantua Lakes the water residence time is even less (from few days up to 1 month), but the basins are closer to lentic waters (few $\mathrm{cm} \mathrm{s}^{-1}$ ), favouring phytoplankton growth and accumulation and therefore a heterogeneous pattern.

Focusing on the period of major productivity of the phytoplankton (March-September), the coefficient of variation of Chl-a concentration increased up to $70 \%$ in the Superior Lake and in particular in the lotic portion of this
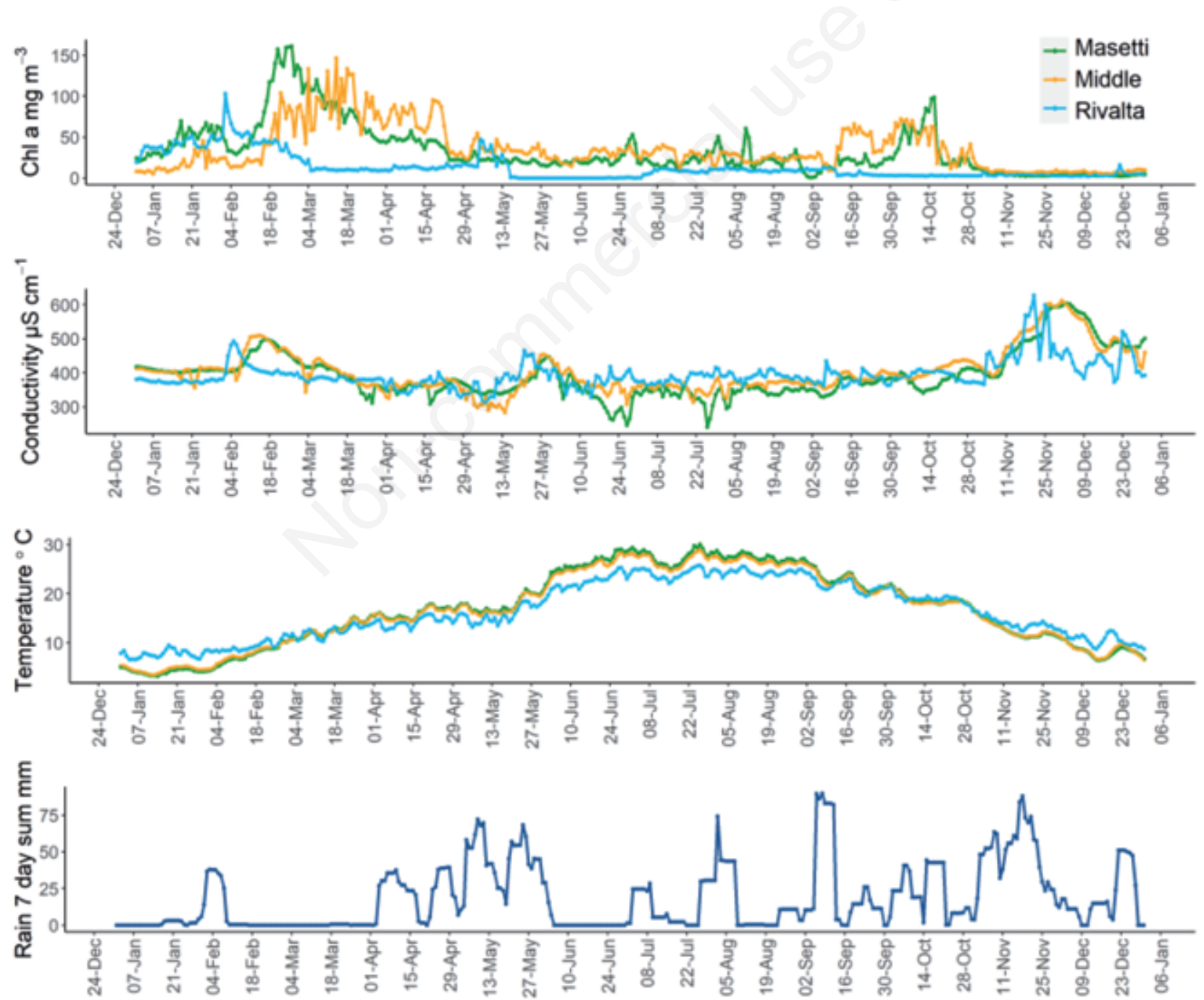

Fig. 6. Results from the multiparameter probe for 2019 for Rivalta, Middle Lake and Masetti dam stations for Chl-a, conductivity, lake water temperature and the sum of seven day antecedent rainfall. Vasarina had excessive data gaps and is not presented. 
sub-basin, where the magnitude of the variation of Chl-a was highest. The maximum Chl-a concentration map produced highlighted the portion of the lakes where the phytoplankton blooms were more intense, which is very useful in terms of monitoring both for the choice of a proper site for in situ sampling and subsequent identification of algal species (e.g., cyanobacteria) and for eventually developing an early warning system. This system could include a combination of critical parameters such as phytoplankton abundance, water renewal time, oxygen concentration, water temperatures, that under or over a given threshold can promote hypoxia or anoxia events in large portions of the lake and the collapse of the ecosystem, as reported for example in Pinardi et al. (2011) for the Middle Lake. In addition, such systems can be used to inform the public of blooms and update lake shore signage regarding precautions needed. In the eastern portion of the Superior Lake close to the biggest macrophyte stand and upstream of the Vasarina dam is clearly an area with the highest value of Chl-a (Fig. 4). These findings confirm the results reported with a more limited dataset by Pinardi et al. (2015) and Bresciani et al. (2017), suggesting that Chl-a distribution is probably due to the combined effects of water hydrodynamics, water discharge and wind speed. In fact, the area with the highest values is characterized by water stagnation which can favour phytoplankton blooms and accumulation in nutrient rich waters. Extending previous finding for the Superior Lake to the Middle and Inferior lakes we can speculate that probably water circulation is not homogeneous in each sub-basin, but it can be influenced by lake morphology and by the presence of floating-leaved or emergent macrophyte stands, that are an obstacle to water circulation (i.e., in the Superior and Middle Lake). More robust conclusions can be formulated when a hydrodynamic model is computed also for the Middle and Inferior lakes. Moreover, it is acknowledged that phytoplankton composition and abundance is shaped by the presence of macrophytes as they influence and regulate water quality because of their effects on allelopathy, nutrient competition, shading and hypoxic/anoxic conditions (Izaguirre et al., 2010; Naselli-Flores and Barone, 2012). As an example, Avigliano et al. (2014) suggested that water depth and development of macrophytes are the key factors in shaping phytoplankton structure in a warm-temperate wetland characterized by drought/flood periods.

Our results shown the great advantages of using remote sensing data in terms of spatial (coverage of the whole lake system simultaneously, with a high number of pixels that each add up to give a large number of data extracted) and temporal (i.e., 27 maps in this study) scales, allowing assessments of data accuracy and uncertainty both in Chl-a concentration and trophic status classification. On the other hand, a limit of this technique is that it is related to the upper euphotic layers of the water, instead the in situ Chl-a data collected during the routine operational monitoring by ARPA is integrated along the depth of the water column from 0.5 to $2 \mathrm{~m}$ in the Mantua Lakes, but this latter approach is independent from the water transparency that varies seasonally. A low frequency and point resolution dataset can be less robust and less representative of the quality status of a complex and heterogeneous aquatic ecosystem, such as the Mantua Lakes, as found for the period analysed in the underestimation of the annual trophic-status using the ARPA dataset compared to the satellite-based classification (see Fig. 2 in Supplementary material 3 ).

Examining the Chl-a data for the high frequency buoys revealed two main bloom events in the lake in the spring and late summer of 2019 the timing and intensity of which was likely controlled by precipitation events. The increase in conductivity and Chl-a was almost immediate in the uppermost site Rivalta with a delay of about two weeks for a response to be noted in the lower lakes, at Middle Lake and Masetti dam sites. While this is indicative of the time needed for a nutrient pulse to move through the system in spring it also shows the benefits of positioning a sensor in the upper part of a chain of lakes to allow for forewarning and the planning of management actions in response to bloom events. The importance of precipitation was supported by its inclusion in NPMR analysis for all three sites although the influence of seasonality as accounted for by the inclusion of the DOY variable was usually the most important factor as indicated by sensitivity values. Temperature was also interchangeable with precipitation in the models probably as a result of it also reflecting seasonality but also because of the fact that rainfall events were typically accompanied by a drop in temperature. It therefore may act as a proxy for seasonality and influx. Apart from the different seasonal timings, generally the Chl-a concentrations were similar between Middle Lake and Masetti dam despite lake chains being effective nutrient retention sinks, as evidenced by the decline in annual median phosphate concentrations through the system (Stewart et al., 1976; Arheimer and Brandt, 1998). The influence of nutrient retention and its visibility in reduced Chl-a concentrations is likely dependent on scale, both spatial and temporal, water retention time (short for these lakes), and connectivity between lakes. Although, Pinardi et al., (2011) measured a net annual export of Chl-a loads (relative to Middle Lake) to the Inferior Lake, as a result of phytoplankton growth owing to high $\mathrm{N}$ and $\mathrm{P}$ availability which is converted into particulate forms (as particulate $\mathrm{N}$ and $\mathrm{P}$ were highly correlated with Chl-a concentration, and $\mathrm{N}$ and $\mathrm{P}$ dissolved forms decreased).

Comparing the results of the buoys for Middle and Inferior lakes (Masetti dam) (Fig. 6) with the satellite im- 
ages (Fig. 1 in Supplementary material 3) we can see that the bloom observed by the buoys was visible on the $8^{\text {th }}$ of March 2019, providing vital supplementary information on phytoplankton spatial distribution. Even if the reason is unclear as to why the spring bloom occurred earlier in Inferior Lake rather than in the upstream Middle Lake. Both lakes have a mean depth of $3 \mathrm{~m}$, possible explanations are that there could be a larger population of zooplankton in Middle Lake reducing bloom growth or localized nutrient input to Inferior Lake promoting growth although data are lacking to support this. For example, Bowes et al. (2016) reported that a possible explanation for the absence of or reduced phytoplankton blooms despite favourable conditions may be the high water temperature that can inhibit phytoplankton groups and stimulate filter feeders and zooplankton grazing, or increasing viral lysis rates.

An intense episode of precipitation in the middle of November 2019 resulted in extremely high nutrient and suspended solid concentrations in the Mantua Lakes water, but low phytoplankton biomass, probably due to the physical disturbance of water and less favourable weather conditions for algal growth. Extreme rainfall may disturb physically the water column (Jones and Elliott, 2007), and can favour the runoff and pulse of dissolved and particulate nutrients and organic matter from the catchment to the rivers and lakes (Weyhenmeyer et al., 2004; Wantzen et al., 2008). These effects can be amplified by flood events. The responses of the biotic compartment to these episodic changes can be complex, heterogeneous and from short to intermediate in duration (Paidere et al., 2007), and can involve variation in the bacterial and phytoplankton community structure and productivity with consequence on the lake metabolism (Jennings et al., 2012).

Extreme weather events are typically unpredictable and limited in duration, and therefore routine monitoring usually misses the biotic and abiotic responses to these events which are now more recurrent and important in the projection of future extreme weather conditions (Jennings et al., 2012). In this scenario, projections of increased warming, increase in extreme events occurrence, changes in fre- quency and severity of storms have already been reported, while major uncertainty is related to precipitation, and wind speed future projection (Beniston et al., 2007; Samuelsson, 2010). However, the consequences of these changes will depend on the climate change direction at a given position and on lake and watershed characteristics and resilience capacity (Staehr and Sand-Jensen, 2006, 2007).

Generally speaking, there is probably no ideal single approach to monitoring lake systems and it is necessary to combine several approaches and sources of information. Essential to this is the cross-validation of products as done here to ensure confidence in data sources. Tab. 3 attempts to summarize the main events in a shallow lake system like Mantua and indicate where each monitoring approach contributes most. For example, high frequency probes are ideal for assessing short term dynamics and assessing the duration of blooms, whereas bloom spatial extent can best be addressed through EO approaches. In contrast, field sampling is essential to understand the nutrient dynamics driving the system, while for management and planning it is essential to incorporate information from all these sources. In accordance with Carvalho et al. (2019), combining these approaches would be a step forward in delivering the improvements in temporal and spatial resolution identified by researchers and river basin managers as a developmental need of Europe's Water Framework Directive. In addition, monitoring an entire system of lakes in this manner has the benefit of applying a holistic approach for the evaluation of the trophic status essential for effective management rather that overfocusing on the detail of complex assessments, a criticism levelled at the WFD (Voulvoulis et al., 2017).

\section{CONCLUSIONS}

In the present global context, water managers have a challenging role to mitigate and control cultural eutrophication processes, often exacerbated by climate change effects. The understanding of the complex relationship at different spatio-temporal scales between biological (i.e.,

Tab. 3. Table of events and knowledge contribution from the different data sources. Presence and relative size of dots indicates attributed importance.

\begin{tabular}{|c|c|c|c|c|}
\hline Events & Earth observation & High frequency probes & Field sampling chemistry & Weather station \\
\hline Rainfall event & & $\bullet$ & $\bullet$ & $\bullet$ \\
\hline Nutrient loading and dynamics & & $\bullet$ & $\bullet$ & - \\
\hline Spring bloom duration & • & $\bullet$ & $\bullet$ & \\
\hline Spring bloom extent & $\bullet$ & & & \\
\hline Late summer bloom duration & - & $\bullet$ & $\bullet$ & \\
\hline Late summer bloom extent & $\bullet$ & & & \\
\hline Subsequent management and planning & $\bullet$ & • & $\bullet$ & \\
\hline
\end{tabular}


phytoplankton abundance) and physico-chemical factors in aquatic ecosystems is still a key research issue. In this context, this research represents a pilot case study of daily and seasonal phytoplankton biomass trends analysis by integrating high frequency in situ data (i.e., multiprobes mounted on buoys) located upstream and downstream along a water system, using the new generation of Sentinel2 MSI images to retrieve spatio-temporal distribution of Chl-a concentration, for a multi-annual period. Mapping of the seasonal and spatial variation of Chl-a concentration gave insights into the intra-lake heterogeneity, identifying zones with higher variability and susceptibility to environmental factors and thus improving strategies for water resource management and planning of monitoring programs. NPMR analysis on high-frequency data allowed the identification of rainfall events as a principal driver in the timing and growth dynamics of phytoplankton, especially for spring and late summer blooms.

Progress in sensor technology allowed the collection of high-frequency and spatially distributed data with the opportunity to better understand and monitor key ecological variables, such as $\mathrm{Chl}-\mathrm{a}$, and their rapid changes at temporal scales not possible with manual field measurements. In addition, water temperature, another key parameter for aquatic environments, which is also part of in situ measurements of this study, can be retrieved with the use of thermal remote sensing, for example with Landsat satellite series, although with a less frequent revisit time and lower spatial resolution than Sentinel-2, they actually provide valuable data for medium-small size lakes (e.g., Sharaf et al., 2019).

Combining high resolution spatial and temporal data improves the understanding of complex fluvial-lake systems. In this context, the availability of data from local, regional and global scales across a network of sites and utilizing remote sensing data, will allow comparative analysis and will be increasingly important due to the global nature of many current pressures, of both temporary or permanent nature on aquatic ecosystems. This integrated approach can allow water managers to have near-real time water quality data fundamental in guiding accurate and efficient management actions in aquatic ecosystem of high nature value.

\section{ACKNOWLEDGMENTS}

The present study is part of the research activities carried out within the Convention between the Institute for Electromagnetic Sensing of the Environment of the National Research Council and the Department of Chemistry, Life Sciences and Environmental Sustainability of the University of Parma. Part of this work was supported by EU Horizon 2020 programme Water-ForCE, grant agreement no. 101004186 and by the WATER-Sat project
(CNR DIT.012.115.001). Sentinel-2 imagery was gathered from Copernicus Open Access Hub and ERA5 meteo-climatic data on the Copernicus Climate Data Store. We acknowledge Mincio Park for providing in situ continuous data from multi-parameters probes. We are very grateful to ARPA Lombardy for providing us in situ physico-chemical monitoring data and AIPO (Mantua branch) for hydrometric level data. We also thank the AERONET Principal Investigator C. Giardino for establishing and maintaining Sirmione_Museo_GC.

\section{REFERENCES}

APHA, AWWA, WPCF, 1981. Standard methods for the examination of water and wastewater. Washington, American Public Health Association.

Arheimer B, Brandt M, 1998. Modelling nitrogen transport and retention in the catchments of Southern Sweden. Ambio 27:471-480.

Ansper A, Alikas K, 2019. Retrieval of chlorophyll a from Sentinel-2 MSI data for the European Union water framework directive reporting purposes. Remote Sens.-Basel 11:64.

Avigliano L, Vinocour A, Chaparro G, Tell G, Allende L, 2014. Influence of re-flooding on phytoplankton assemblages in a temperate wetland following prolonged drought. J. Limnol. 73:838

Beniston M, Stephenson DB, Christensen OB, Ferro CA, Frei C, Goyette S, et al., 2007. Future extreme events in European climate: an exploration of regional climate model projections. Climatic Change 81:71-95.

Bennett MG, Schofield KA, Lee SS, Norton SB, 2017. Response of chlorophyll a to total nitrogen and total phosphorus concentrations in lotic ecosystems: a systematic review protocol. Environ. Evid. 6:1-3.

Bergamino N, Horion S, Stenuite S, Cornet Y, Loiselle S, Plisnier PD, Descy JP, 2010. Spatio-temporal dynamics of phytoplankton and primary production in Lake Tanganyika using a MODIS based bio-optical time series. Remote Sens. Environ. 114:772-780.

Boggero A, Fontaneto D, Morabito G, Volta P, 2014. Limnology in the 21st century: the importance of freshwater ecosystems as model systems in ecology and evolution. J. Limnol. 73:948.

Bolpagni R, Bresciani M, Laini A, Pinardi M, Matta E, Ampe EM, Giardino C, Viarioli P, Bartoli M, 2014. Remote sensing of phytoplankton-macrophyte coexistence in shallow hypereutrophic fluvial lakes. Hydrobiologia 737:67-76.

Bowes MJ, Loewenthal M, Read DS, Hutchins MG, Prudhomme C, Armstrong LK, Harman SA, Wickham HD, Gozzard E, Carvalho L, 2016. Identifying multiple stressor controls on phytoplankton dynamics in the River Thames (UK) using high-frequency water quality data. Sci. Total Environ. 569:1489-1499.

Brentrup JA, Williamson CE, Colom-Montero W, Eckert W, de Eyto E, Grossart HP, Huot Y, Isles PD, Knoll LB, Leach TH, McBride CG, 2016. The potential of high-frequency profiling to assess vertical and seasonal patterns of phytoplankton dynamics in lakes: an extension of the Plankton Ecology Group (PEG) model. Inland Waters 6:565-580. 
Bresciani M, Rossini M, Morabito G, Matta E, Pinardi M, Cogliati S, Julitta T, Colombo R, Braga F, Giardino C. 2013. Analysis of within-and between-day chlorophyll-a dynamics in Mantua Superior Lake, with a continuous spectroradiometric measurement. Mar. Freshw. Res. 64:303-316.

Bresciani M, Giardino C, Lauceri R, Matta E, Cazzaniga I, Pinardi M, Lami A, Austoni M, Viaggiu E, Congestri R, Morabito G, 2017. Earth observation for monitoring and mapping of cyanobacteria blooms. Case studies on five Italian lakes. J Limnol. 76:1565.

Bresciani M, Cazzaniga I, Austoni M, Sforzi T, Buzzi F, Morabito G, Giardino C, 2018. Mapping phytoplankton blooms in deep subalpine lakes from Sentinel-2A and Landsat-8. Hydrobiologia 824:197-214.

Bresciani M, Pinardi M, Free G, Luciani G, Ghebrehiwot S, Laanen M, Peters S, Della Bella V, Padula R, Giardino C, 2020. The use of multisource optical sensors to study phytoplankton spatio-temporal variation in a shallow turbid lake. Water 12:284.

Bukata RP, 2005. Satellite monitoring of inland and coastal water quality: retrospection, introspection, future directions. CRC Press: 272 pp.

Carpenter SR, Stanley EH, Vander Zanden MJ, 2011. State of the world's freshwater ecosystems: physical, chemical, and biological changes. Annu. Rev. Environ. Resour. 36:75-99.

Carpenter SR, 2008. Phosphorus control is critical to mitigating eutrophication. Proc. Natl. Acad. Sci. USA 105:11039-11040.

Carstensen J, Henriksen P, Heiskanen AS, 2007. Summer algal blooms in shallow estuaries: definition, mechanisms, and link to eutrophication. Limnol. Oceanogr. 52:370-384.

Carvalho L, Mackay EB, Cardoso AC, Baattrup-Pedersen A, Birk S, Blackstock KL, Borics G, Borja A, Feld CK, Ferreira MT, 2019. Protecting and restoring Europe's waters: An analysis of the future development needs of the water framework directive. Sci. Total Environ. 658:1228-38.

Carvalho L, McDonald C, de Hoyos C, Mischke U, Phillips G, Borics G, Poikane S, Skjelbred B, Solheim AL, van Wichelen J, Cardoso AC, Cadotte M, 2013. Sustaining recreational quality of European lakes: minimizing the health risks from algal blooms through phosphorus control. J. Appl. Ecol. 50:315-323.

Catherine A, Escoffier N, Belhocine A, Nasri AB, Hamlaoui S, Yéprémian C, Bernard C, Troussellier M, 2012. On the use of the FluoroProbe ${ }^{\circledR}$, a phytoplankton quantification method based on fluorescence excitation spectra for large-scale surveys of lakes and reservoirs. Water Res. 46:1771-84.

Conley DJ, Paerl HW, Howarth RW, Boesch DF, Seitzinger SP, Havens KE, Lancelot C, Likens GE, 2009. Controlling eutrophication: nitrogen and phosphorus. Science 323:1014-5.

De Tezanos Pinto P, O'Farrell I, 2014. Regime shifts between free-floating plants and phytoplankton: a review. Hydrobiologia 740:13-24.

Dörnhöfer K, Oppelt N, 2016. Remote sensing for lake research and monitoring - Recent advances. Ecol. Indic. 64:105-122.

Dörnhöfer K, Klinger P, Heege T, Oppelt N, 2018. Multi-sensor satellite and in situ monitoring of phytoplankton development in a eutrophic-mesotrophic lake. Sci. Total Environ. 612:1200-1214.

Duan HT, Ma RH, Xu XF, Kong FX, Zhang SX, Kong WJ, et al., 2009. Two decade reconstruction of algal blooms in
China's Lake Taihu. Environ. Sci. Technol. 43:3522-3528.

European Commission, 2000. Directive 2000/60/EC of the European Parliament and of the council of 23rd October 2000 establishing a framework for community action in the field of water policy. Official Journal of the European Communities, L327/1, Brussels.

Falkowski P, Kiefer DA, 1985. Chlorophyll a fluorescence in phytoplankton: relationship to photosynthesis and biomass. J. Plankton Res. 7:715-31.

Gilerson AA, Gitelson AA, Zhou J, Gurlin D, Moses W, Ioannou I, Ahmed SA, 2010. Algorithms for remote estimation of chlorophyll-a in coastal and inland waters using red and near infrared bands. Opt. Express 18:24109-24125.

Gillett ND, Luttenton MR, Steinman AD, 2015. Spatial and temporal dynamics of phytoplankton communities in a Great Lakes drowned river-mouth lake (Mona Lake, USA). J. Limnol. 74:1055.

Ha NTT, Koike K, Nhuan MT, Canh BD, Thao NTP, Parsons M, 2017. Landsat 8/OLI two bands ratio algorithm for chlorophyll a concentration mapping in hypertrophic waters: An application to West Lake in Hanoi (Vietnam). IEEE J. Sel. Top. Appl. 10:4919-4929.

Hamilton DP, O'Brien KR, Burford MA, Brookes JD, McBride CG, 2010. Vertical distributions of chlorophyll in deep, warm monomictic lakes. Aquat. Sci. 72:295-307.

Hanjra MA, Qureshi ME, 2010. Global water crisis and future food security in an era of climate change. Food Pol. 35:365377.

Hestir EL, Brando VE, Bresciani M, Giardino C, Matta E, Villa P, Dekker AG, 2015. Measuring freshwater aquatic ecosystems: The need for a hyperspectral global mapping satellite mission. Remote Sens. Environ. 167:181-195.

Huang C, Shi K, Yang H, Li Y, Zhu AX, Sun D, Xu L, Chen X, 2015. Satellite observation of hourly dynamic characteristics of algae with Geostationary Ocean Color Imager (GOCI) data in Lake Taihu. Remote Sens. Environ. 159:278-287.

Huot Y, Babin M, 2010. Overview of fluorescence protocols: theory, basic concepts, and practice, p. 31-74. In: D.J. Suggett, M.A. Borowitzka and O. Prášil (eds.), Chlorophyll a fluorescence in aquatic sciences: Methods and applications. Dordrecht, Springer.

Huovinen P, Ramírez J, Caputo L, Gómez I, 2019. Mapping of spatial and temporal variation of water characteristics through satellite remote sensing in Lake Panguipulli, Chile. Sci. Total Environ. 679:196-208.

Jennings E, Jones S, Arvola L, Staehr PA, Gaiser E, Jones ID, Weathers KC, Weyhenmeyer GA, Chiu C-Y, De Eyto E, 2012. Effects of weather-related episodic events in lakes: An analysis based on high-frequency data. Freshwater Biol. 57:589-601.

Jeppesen E, Jensen JP, Jensen C, Faafeng B, Hessen DO, Søndergaard M, Lauridsen T, Brettum P, Christoffersen K, 2003. The impact of nutrient state and lake depth on top-down control in the pelagic zone of lakes: a study of 466 lakes from the temperate zone to the Arctic. Ecosystems 6:313-325.

Jindal R, Thakur RK, 2013. Diurnal variations of plankton diversity and physico-chemical characteristics of Rewalsar Wetland, Himachal Pradesh, India. Rec. Res. Sci. Technol. 5:4-9.

Jones ID, Elliott JA, 2007. Modelling the effects of changing re- 
tention time on abundance and composition of phytoplankton species in a small lake. Freshwater Biol. 52:988-997.

Kaplan DM, Largier JL, Navarrete S, Guiñez R, Castilla JC, 2003. Large diurnal temperature fluctuations in the nearshore water column. Estuar. Coast. Shelf S. 57:385-398.

Kiefer I, Odermatt D, Anneville O, Wüest A, Bouffard D, 2015. Application of remote sensing for the optimization of in-situ sampling for monitoring of phytoplankton abundance in a large lake. Sci. Total Environ. 527:493-506.

Klemas V, 2013. Remote sensing of emergent and submerged wetlands: an overview. Int. J. Remote Sens. 34:6286-6320.

Izaguirre I, Pizarro H, de Tezanos Pinto P, Rodríguez P, O'Farrell I, Unrein F, Gasol JM, 2010. Macrophyte influence on the structure and productivity of photosynthetic picoplankton in wetlands. J. Plankton Res. 32:221-238.

Laney SR, 2010. In situ measurement of variable fluorescence transients, p. 19-30. In: D.J. Suggett, M.A. Borowitzka and O. Prášil (eds.), Chlorophyll a fluorescence in aquatic sciences: Methods and applications. Dordrecht, Springer.

Leal MC, Sá C, Nordez S, Brotas V, Paula J, 2009. Distribution and vertical dynamics of planktonic communities at Sofala Bank, Mozambique. Estuar. Coast. Shelf S. 84:605-616.

Lindell T, Pierson D, Premazzi G, 1999. Manual for monitoring European lakes using remote sensing techniques. Joint Research Centre, ISPRA: $161 \mathrm{pp}$.

Liu X, Wang M, Shi W, 2009. A study of a Hurricane Katrinainduced phytoplankton bloom using satellite observations and model simulations. J. Geophys. Res.-Oceans 114:4934.

Matthews MW, 2017. Bio-optical modeling of phytoplankton chlorophyll-a, p. 157-188. In: D.R. Mishra, I. Ogashawara and A.A. Gitelson (eds.), Bio-optical modeling and remote sensing of inland waters. Amsterdam, Elsevier.

McCune B, 2011. Nonparametric multiplicative regression for habitat modeling. Oregon State University.

Mobley CD, 1999. Estimation of the remote-sensing reflectance from above-surface measurements. Appl. Opt. 38:7442-7455.

Moore SK, Trainer VL, Mantua NJ, Parker MS, Laws EA, Backer LC, Fleming LE, 2008. Impacts of climate variability and future climate change on harmful algal blooms and human health. Environ. Health 7:1-12.

Morrison JR, 2003. In situ determination of the quantum yield of phytoplankton chlorophyll a fluorescence: A simple algorithm, observations, and a model. Limnol. Oceanogr. 48:618-631.

Moss B, 2012. Cogs in the endless machine: lakes, climate change and nutrient cycles: a review. Sci. Total Environt. 434:130-142.

Naselli-Flores L, Barone R, 2012. Phytoplankton dynamics in permanent and temporary Mediterranean waters: is the game hard to play because of hydrological disturbance? Hydrobiologia 701:219:233.

Nõges P, Tuvikene L, 2012. Spatial and annual variability of environmental and phytoplankton indicators in Lake Võrtsjärv: implications for water quality monitoring. Est. J. Ecol. 61:227-246.

Odermatt D, Pomati F, Pitarch J, Carpenter J, Kawka M, Schaepman M, Wüest A, 2012. MERIS observations of phytoplankton blooms in a stratified eutrophic lake. Remote Sens. Environ. 126:232-239.

Organization for Economic Cooperation and Development
(OECD), 1982. Eutrophication of waters. Monitoring, assessment and control. Final report, OECD cooperative programme on monitoring of inland waters (eutrophication control). Paris, OECD: 154 pp.

Oppelt N, Scheiber R, Wegmann M, Taubenböck H, Gege P, Berger M, 2015. Fundamentals of remote sensing for terrestrial applications: evolution, current state-of-art and future possibilities, p. 61-86. In: T.S. Thenkabail (ed.), Remotely sensed data characterization, classification, and accuracies. CRC Press.

Paidere J, Gruberts D, Škute A, Druvietis I, 2007. Impact of two different flood pulses on planktonic communities of the largest floodplain lakes of the Daugava River (Latvia). Hydrobiologia 592:303-314.

Palmer SC, Kutser T, Hunter PD, 2015. Remote sensing of inland waters: Challenges, progress and future directions. Remote Sens. Environ. 157:1-8.

Pan Y, Qiu L, 2019. A submersible in-situ highly sensitive chlorophyll fluorescence detection system. IOP Conference Series: Materials Science and Engineering 677:022065.

Pearson RK, Neuvo Y, Astola J, Gabbouj M, 2016, Generalized hampel filters. EURASIP J. Adv. Sign. Process. 1:1-8.

Pinardi M, Bartoli M, Longhi D, Viaroli P, 2011. Net autotrophy in a fluvial lake: the relative role of phytoplankton and floating-leaved macrophytes. Aquat. Sci. 73:389-403.

Pinardi M, Fenocchi A, Giardino C, Sibilla S, Bartoli M, Bresciani $\mathrm{M}, 2015$. Assessing potential algal blooms in a shallow fluvial lake by combining hydrodynamic modelling and remote-sensed images. Water 7:1921-1942.

Pinardi M, Bresciani M, Villa P, Cazzaniga I, Laini A, Tóth V, Fadel A, Austoni M, Lami A, Giardino C, 2018. Spatial and temporal dynamics of primary producers in shallow lakes as seen from space: Intra-annual observations from Sentinel2A. Limnologica 72:32-43.

Pinardi M, Soana E, Bresciani M, Villa P, Bartoli M, 2020. Upscaling nitrogen removal processes in fluvial wetlands and irrigation canals in a patchy agricultural watershed. Wetlands Ecol. Manage.28:297-313.

Pinardi M, Villa P, Free G, Giardino C, Bresciani M, 2021. Evolution of native and alien macrophytes in a fluvial-wetland system using long-term satellite data. Wetlands 41:1-14.

Polat SEVIM, Akiz A, Olgunoglu MP, 2005. Daily variations of coastal phytoplankton assemblages in summer conditions of the northeastern Mediterranean (Bay of İskenderun). Pak. J. Botany 37:715.

Reynolds CS, 2006. The ecology of freshwater phytoplankton. Cambridge: Cambridge University Press: $551 \mathrm{pp}$.

Samuelsson P, 2010. Using regional climate models to quantify the impact of climate change on lakes, p. 15-32. In: G. George (ed.), The impact of climate change on European Lakes. Dordrecht, Springer.

Schaeffer BA, Schaeffer KG, Keith D, Lunetta RS, Conmy R, Gould RW, 2013. Barriers to adopting satellite remote sensing for water quality management. Int. J. Remote Sens. 34:7534-7544.

Sharaf N, Fadel A, Bresciani M, Giardino C, Lemaire BJ, Slim K, Faour G, Vinçon-LeiteB, 2019. Lake surface temperature retrieval from Landsat-8 and retrospective analysis in Karaoun Reservoir, Lebanon. J. Appl. Remote Sens. 13:044505. 
Smith V, 2003. Eutrophication of freshwater and coastal marine ecosystems a global problem. Environ. Sci. Pollut. Res.10:126-39.

Staehr PA, Sand-Jensen KAJ, 2006. Seasonal changes in temperature and nutrient control of photosynthesis, respiration and growth of natural phytoplankton communities. Freshwater Biol. 51:249-262.

Staehr PA, Sand-Jensen K, 2007. Temporal dynamics and regulation of lake metabolism. Limnol. Oceanogr. 52:108-120.

Steinman AD, Lamberti GA, Leavitt PR, 2006. Biomass and pigments of benthic algae, p. 357-379. In: FR Hauer and GE Lamberti (eds.), Methods in stream ecology. Burlington, Academic Press.

Stendera S, Adrian R, Bonada N, Cañedo-Argüelles M, Hugueny B, Januschke K, et al., 2012. Drivers and stressors of freshwater biodiversity patterns across different ecosystems and scales: a review. Hydrobiologia 696:1-28.

Stewart WDP, May E, Tuckwell SB, 1976. Nitrogen and phosphorus from agricultural land and urbanization and their fate in shallow freshwater lochs, p. 276-305. In: W. Dermott and J.R. Gasser (eds.) Agriculture and water quality, Technical Bulletin 32. London, HMSO.

Toming K, Kutser T, Laas A, Sepp M, Paavel B, Nõges T, 2016. First experiences in mapping lake water quality parameters with Sentinel-2 MSI imagery. Remote Sens. 8:640.

Topp SN, Pavelsky TM, Jensen D, Simard M, Ross MR, 2020. Research trends in the use of remote sensing for inland water quality science: Moving towards multidisciplinary applications. Water 12:169.

Tyler AN, Hunter PD, Spyrakos E, Groom S, Constantinescu AM, Kitchen J, 2016. Developments in Earth observation for the assessment and monitoring of inland, transitional, coastal and shelf-sea waters. Sci. Total Environ. 572:1307-1321.
Vargas-Lopez IA, Rivera-Monroy VH, Day JW, Whitbeck J, Maiti K, Madden CJ, Trasviña-Castro A, 2021. Assessing chlorophyll a spatiotemporal patterns combining in situ continuous fluorometry measurements and Landsat 8/OLI data across the Barataria Basin (Louisiana, USA). Water 13:512.

Vermote EFTD, Tanré D, Deuzé JL, Herman M, Morcrette JJ, Kotchenova SY, 2006. Second simulation of a satellite signal in the solar spectrum-vector (6SV). 6S User Guide Version 3.

Villa P, Pinardi M, Tóth VR, Hunter PD, Bolpagni R, 2017. Remote sensing of macrophyte morphological traits: implications for the management of shallow lakes. J. Limnol. $76: 1629$.

Voulvoulis N, Arpon KD, Giakoumis T, 2017. The EU Water Framework Directive: From great expectations to problems with implementation. Sci. Total Environ. 575:358-366.

Wang M, Shi W, Tang J, 2011. Water property monitoring and assessment for China's inland Lake Taihu from MODISAqua measurements. Remote Sens. Environ. 115:841-854.

Wantzen KM, Junk WJ, Rothhaupt KO, 2008. An extension of the floodpulse concept (FPC) for lakes, p. 151-170. In: K.M. Wantzen, K.O. Rothhaupt, M. Mörtl, M. Cantonati, L.G. Tóth and P. Fischer (eds.), Ecological effects of water-level fluctuations in lakes. Dordrecht, Springer.

Weyhenmeyer GA, Willén E, Sonesten L, 2004. Effects of an extreme precipitation event on water chemistry and phytoplankton in the Swedish Lake Mälaren. Boreal Environ. Res. 9:409-420.

Woods T, Kaz A, Giam X, 2021. Phenology in freshwaters: a review and recommendations for future research. Ecography. Online ahead of Print.

Zhang M, Duan H, Shi X, Yu Y, Kong F, 2012. Contributions of meteorology to the phenology of cyanobacterial blooms: implications for future climate change. Water Res. 46:442-452. 